Elsevier Science Publishers B.V., Amsterdam - Printed in The Netherlands

\title{
Changes in Physico-Chemical Properties of some Clay Minerals by Reducing Extraction Reagents
}

\author{
E. HELIOS RYBICKA and W. CALMANO \\ Academy of Mining and Metallurgy, Al. Mickiewicza 30, 30-059 Krakow (Poland) \\ Technical University Hamburg-Harburg, Eissendorferstr. 38, 2100 Hamburg 90 (Fed. Rep. \\ Germany)
}

(Received September 16, 1986; accepted after revision July 2, 1987)

\begin{abstract}
Helios Rybicka, E. and Calmano, W., 1988. Changes in physico-chemical properties of some clay minerals by reducing extraction reagents. Appl. Clay Sci., 3: 75-84.
\end{abstract}

An extraction sequence in three steps with buffered hydroxylamine hydrochloride, oxalate and dithionite solutions was used for removal of Fe-oxide coatings from standard clay minerals: kaolinite, illite and mixed layer smectite/illite. After each extraction step the cation exchange capacity, specific surface area and the concentrations of $\mathrm{Al}, \mathrm{Si}, \mathrm{Fe}, \mathrm{Mg}, \mathrm{K}$ and $\mathrm{Ca}$ in solution were measured.

For all minerals the specific surface area increases after treatment with hydroxylamine hydrochloride and oxalate, but it decreases after treatment with dithionite solution. The cation exchange capacity shows no significant change for smectite/illite, a small decrease for illite and a continuous increase for kaolinite after treatment with the extractants.

$\mathrm{K}, \mathrm{Ca}$, and $\mathrm{Mg}$ are mainly extractable by hydroxylamine hydrochloride. After each extraction step an additional exchange of these cations could be observed by treatment with ammonium acetate.

\section{INTRODUCTION}

In studies of chemical forms of heavy metals in sediments, suspended matter, contaminated dredged material and waste water suspensions different extraction methods are applied (Gupta and Chen, 1975; Gibbs, 1977; Calmano and Förstner, 1983). With these methods it is possible to estimate bonding stabilities in different phases and mobilities of heavy metals as well as shortand middle-term chemical reactions which influence the availability by organisms.

These extraction procedures are not as selective and specific as sometimes states. They cannot exactly differentiate what portion of a metal is bound by a relatively weak physical or more stable chemical sorption (including copre- 


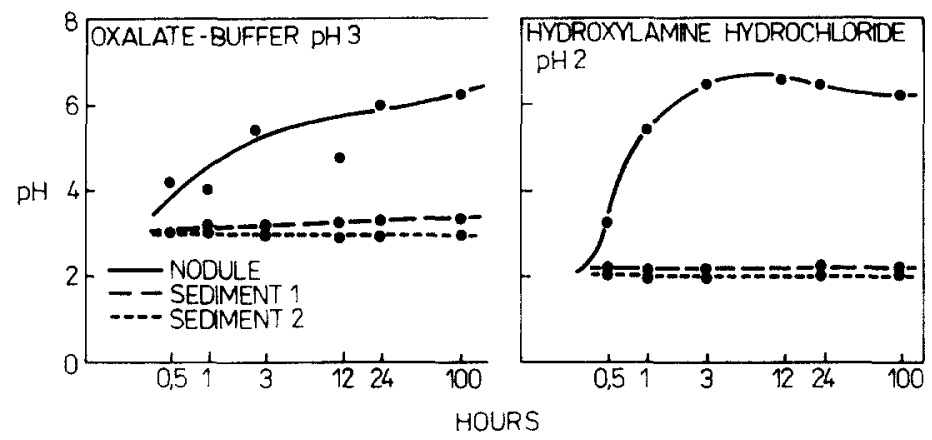

Fig. 1. Changes of $\mathrm{pH}$ values during chemical treatment of nodule and sediment material (Peru Basin) with oxalate and hydroxylamine buffer solutions. Solid/solution ratio $=500 \mathrm{mg} / 50 \mathrm{ml}$ (Pfeiffer et al., 1982).

cipitation and/or isomorphic substitution ), and what portions exist as discrete forms of precipitation compounds. Therefore only the application of chemical extraction procedures under favourable conditions can show relative relationships between sediment phases and chemical bond of a metal.

An extraction sequence which has been applied for study of contaminated sediments (Förstner and Calmano, 1982) includes the following steps separating the reducible phases: (a) easily reducible fraction, e.g. Mn-oxides and amorphous $\mathrm{Fe}$-oxidehydrates by treatment with hydroxylamine hydrochloride; (b) moderately reducible fraction, e.g. poorly crystallized Fe-oxidehydrates by treatment with an oxalate buffer; and (c) heavily reducible $\mathrm{Fe}$ compounds by extraction with a citrate-dithionite buffer.

Systematic experiments by Pfeiffer et al. (1982) showed that dissolution rates for single extraction reagents are influenced by shaking time, solid/solution ratios and amount of solvent, and thus standardized conditions have to be chosen. Especially important is the control of $\mathrm{pH}$.

Fig. 1 shows the time-dependency of $\mathrm{pH}$ for the reducing agents hydroxylamine hydrochloride and oxalate. In both cases the solid/solution ratio was $500 \mathrm{mg} / 50 \mathrm{ml}$. Negligible $\mathrm{pH}$ changes in the sediment samples 1 and 2 indicate nearly ideal conditions. The nodule sample, however, shows increasing $\mathrm{pH}$ values with time. This effect is due to a greater portion of reducible components and an enhanced consumption of hydrogen ions during the chemical reaction. For optimal conditions also mineralogical composition of the samples has to be considered.

In addition to $\mathrm{Fe}$ - and $\mathrm{Mn}$-oxides important representatives of natural solids are the clay minerals which play a significant role in the fixation of heavy metals. The different clays show different physico-chemical behaviour in ion exchange capacity, specific surface area and layer charge. To investigate the influence of reducing reagents on this behaviour the three above-mentioned 
TABLE I

Physico-chemical properties of the examined clay minerals

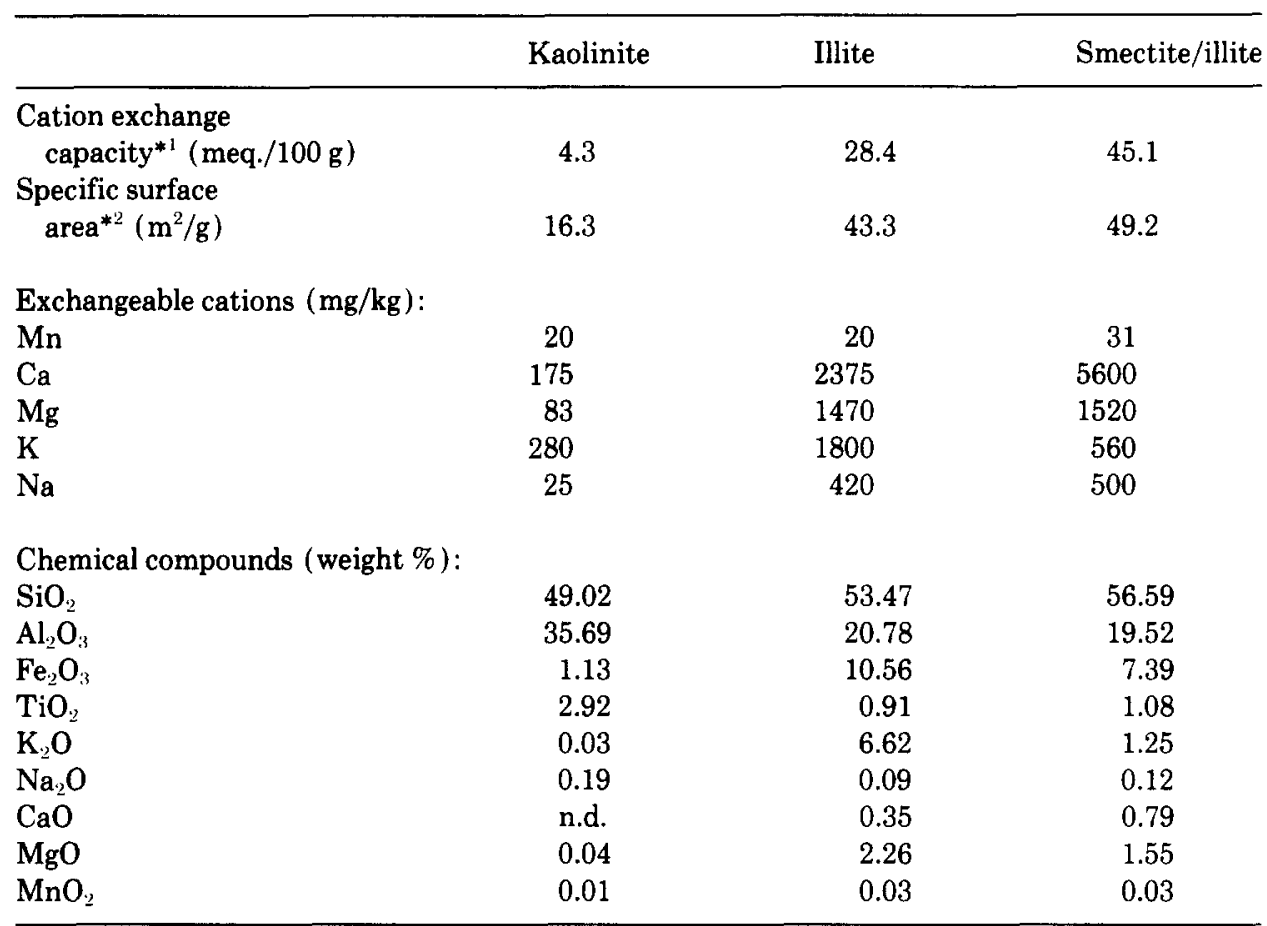

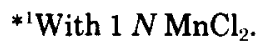

${ }^{* 2} \mathrm{BET}$ method with $\mathrm{N}_{2}$.

extraction steps were applied on the examples of kaolinite, illite and mixed layer smectite/illite.

\section{MATERIALS AND METHODS}

The three clay minerals used in the present study were:

(1) Georgia "poor" kaolinite, showing a low degree of structural order. It is medium grained with a specific surface area of $16 \mathrm{~m}^{2} / \mathrm{g}$.

(2) Silver Hill illite, Montana. The sample (fraction $<2 \mu \mathrm{m}$ ) is a monomineral. No swelling layers have been detected by X-rays. Its cation exchange capacity is not very high, and the mainly exchangeable cations are Ca and $\mathrm{Mg}$.

(3) Konin smectite/illite (fraction $<2 \mu \mathrm{m}$ ). This fraction was isolated from the Poznan clay near Konin, Poland. About $70 \%$ of the principal mineral consists of mixed-layer smectite/illite. The sample also contains illite, some kaolinite and some traces of quartz. The content of swelling layers determined by $\mathrm{X}$-ray diffraction is about $70 \%$. The clay is characterized by not very high 


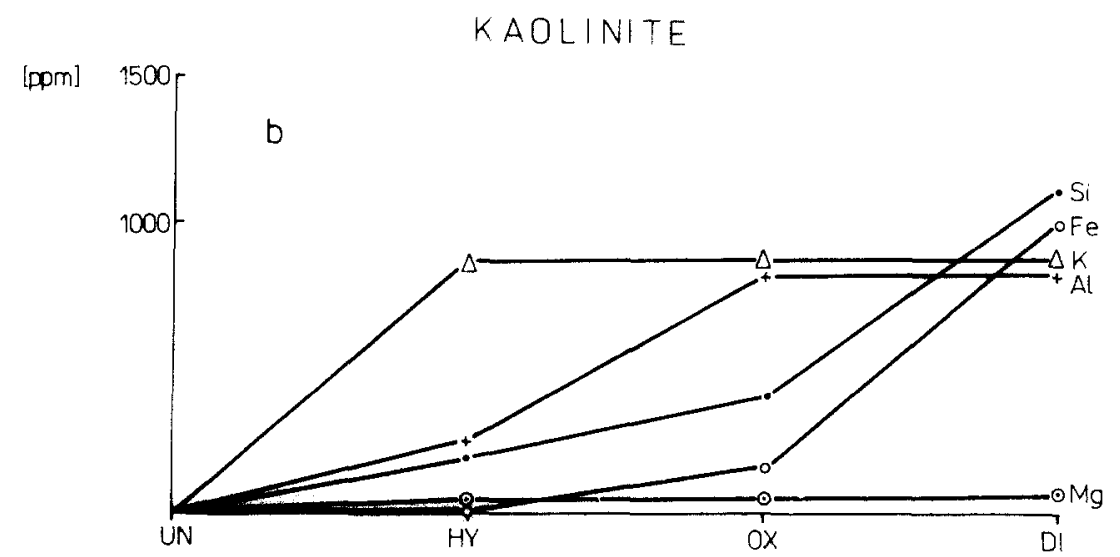

[\%]

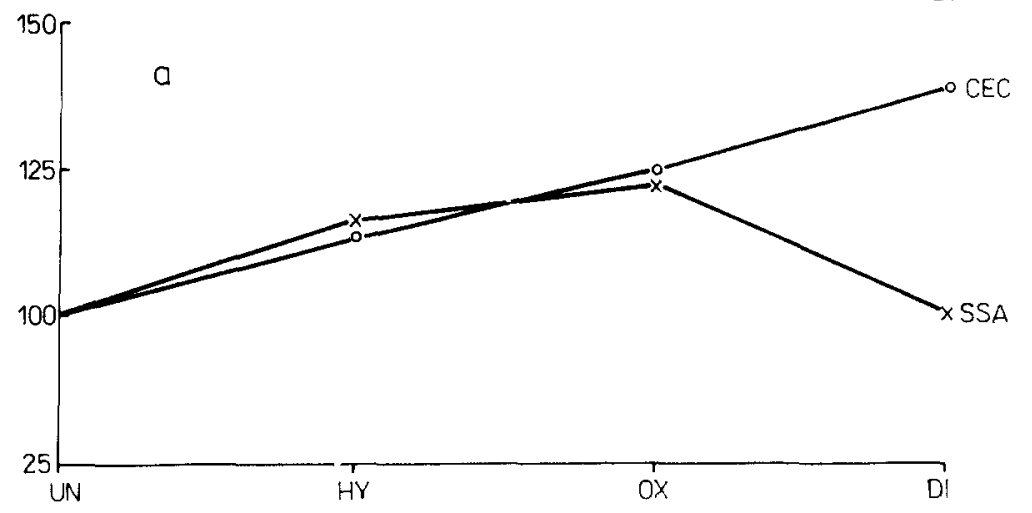

Fig. 2. Kaolinite: (a) Cation exchange capacity (CEC), specific surface area (SSA), and (b) extractable $\mathrm{Si}, \mathrm{Fe}, \mathrm{Al}, \mathrm{K}$ and $\mathrm{Mg}$ for untreated samples (UN), after treatment with hydroxylamine hydrochloride (HY), oxalate buffer (OX) and dithionite (DI). The value of the untreated sample is 100 .

cation exchange capacity ( $45 \mathrm{meq} . / 100 \mathrm{~g}$ ), and its specific surface area is 45 $\mathrm{m}^{2} / \mathrm{g}$. The mainly exchangeable cations are $\mathrm{Ca}$ and $\mathrm{Mg}$.

The characteristics of the clay minerals, such as cation exchange capacity (CEC) and exchangeable cations, specific surface area (SSA) as well as chemical compositions are given in Table I.

The clay minerals were successively treated with: (1) $0.1 M$ hydroxylamine

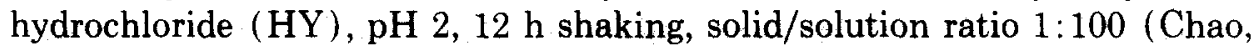
1972); (2) $0.2 \mathrm{M}$ ammonium oxalate $+0.2 \mathrm{M}$ oxalic acid ( $\mathrm{OX}), \mathrm{pH} 3,24 \mathrm{~h}$ shaking, solid/solution ratio 1:100 (Schwertmann, 1964); and (3) $0.05 \mathrm{M}$ sodium dithionite $+0.27 \mathrm{M}$ sodium citrate (DI), $\mathrm{pH} 5.8,12 \mathrm{~h}$ shaking, solid/solution ratio 1:100 (Holmgren, 1967).

$1 \mathrm{~g}$ solid substance was suspended in $100 \mathrm{ml}$ extraction solution, shaken for $24 \mathrm{~h}$ and then centrifuged. After each extraction step the solution was filtered $(0.45 \mu \mathrm{m})$ and analyzed for $\mathrm{Si}, \mathrm{Al}, \mathrm{Fe}, \mathrm{Mg}, \mathrm{Ca}$ and $\mathrm{K}$ by atomic absorption 

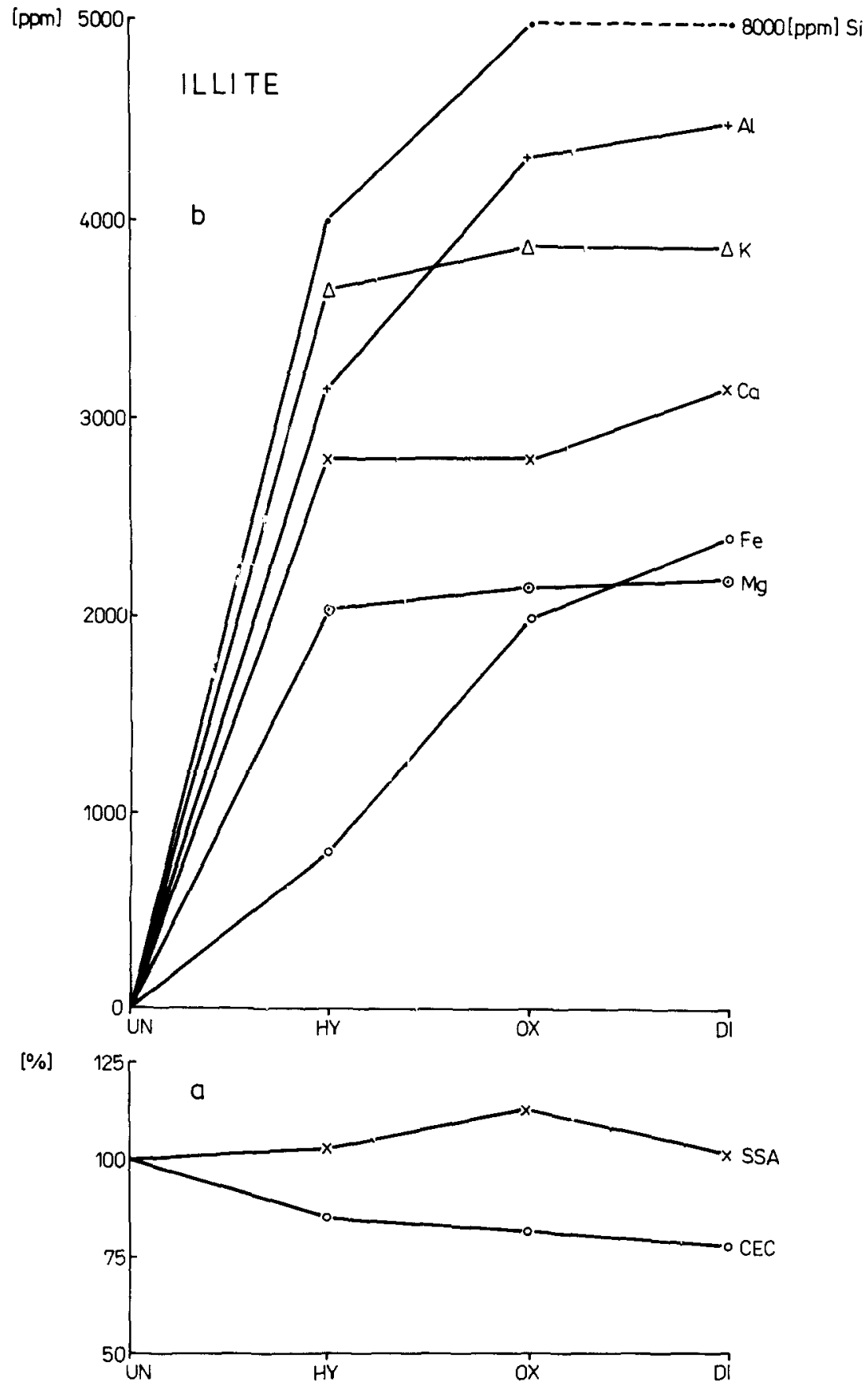

Fig. 3. Illite: (a) Cation exchange capacity (CEC), specific surface area (SSA), and (b) extractable $\mathrm{Si}, \mathrm{Fe}, \mathrm{Al}, \mathrm{K}, \mathrm{Ca}$ and $\mathrm{Mg}$ for untreated samples (UN), after treatment with hydroxylamine hydrochloride (HY), oxalate buffer (OX) and dithionite (DI). The value of the untreated sample is 100 . 


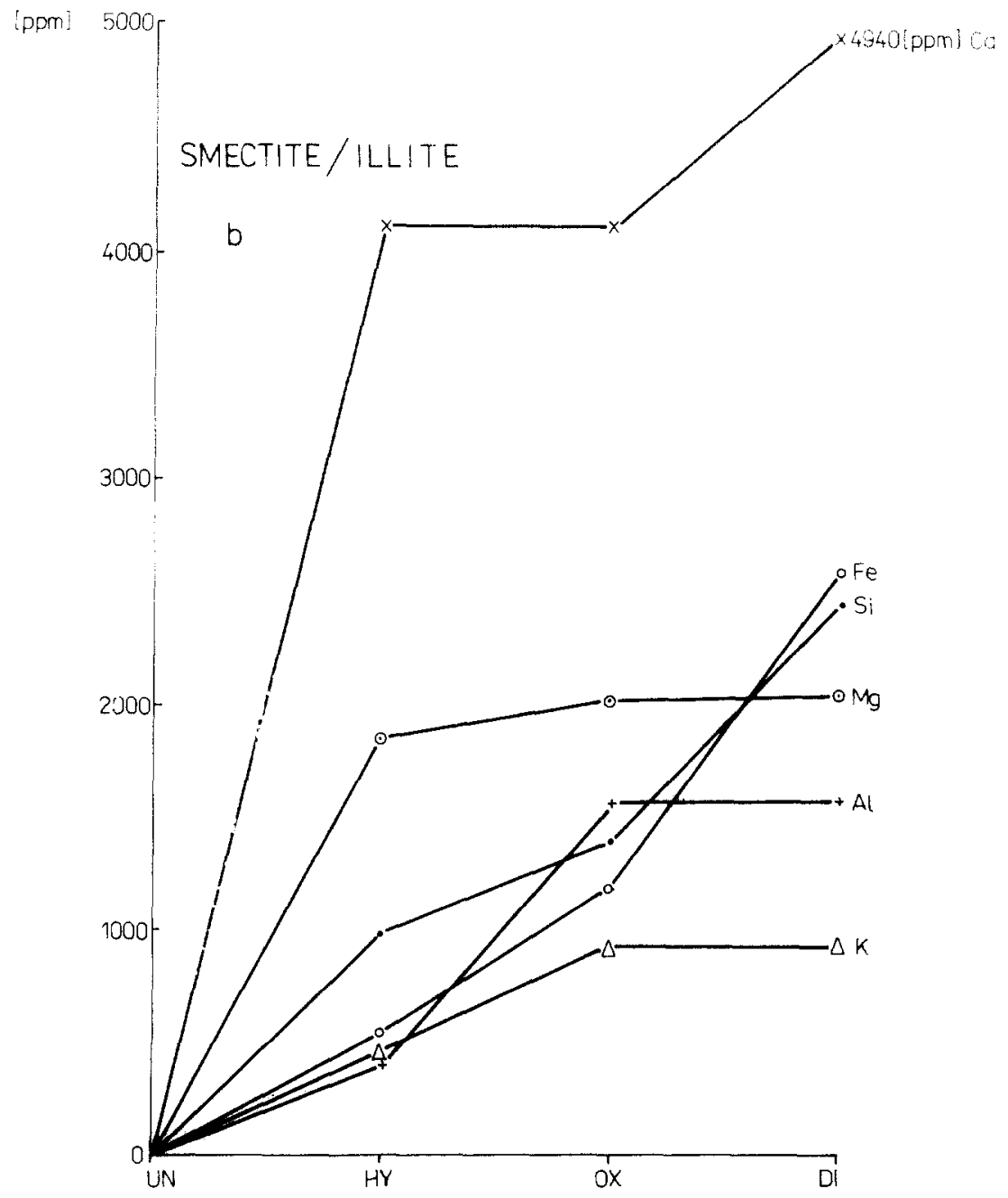

$[\%]$

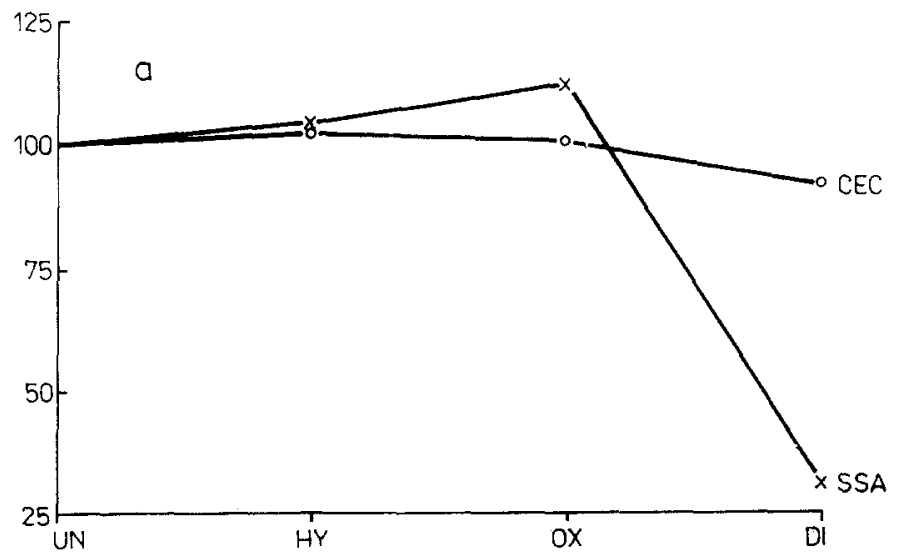

Fig. 4. Smectite/illite: (a) Cation exchange capacity (CEC), specific surface area (SSA), and (b) extractable $\mathrm{Si}, \mathrm{Fe}, \mathrm{Al}, \mathrm{K}, \mathrm{Ca}$ and $\mathrm{Mg}$ for untreated samples (UN), after treatment with hy. droxylamine hydrochloride (HY), oxalate buffer (OX) and dithionite (DI). The value of the untreated sample is 100 . 

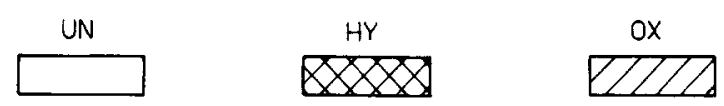

DI
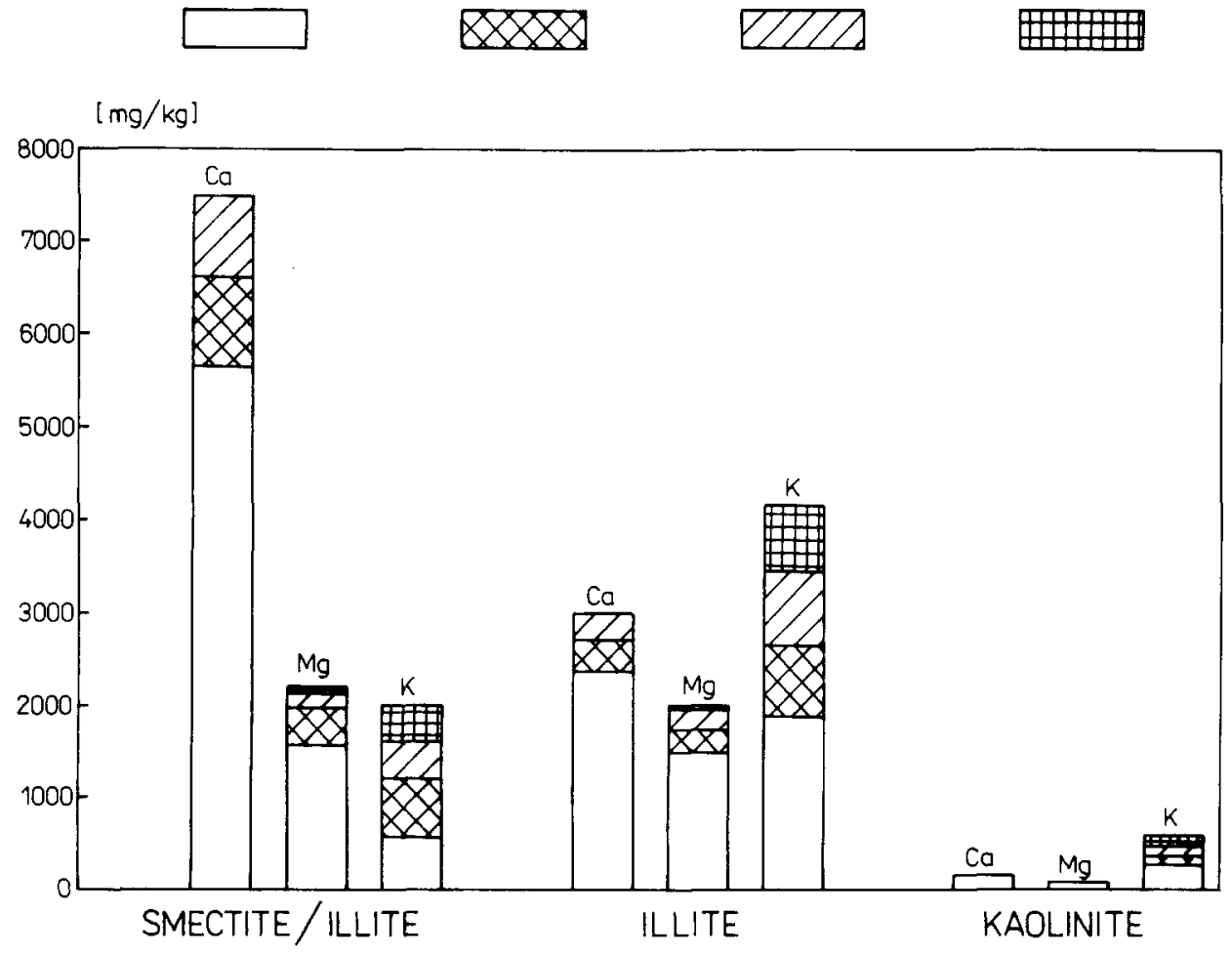

Fig. 5. Ammonium acetate extractable $\mathrm{Ca}, \mathrm{Mg}$ and $\mathrm{K}$ from smectite/illite, illite and kaolinite for untreated minerals (UN), after treatment with hydroxylamine hydrochloride ( $\mathrm{HY}$ ), oxalate buffer $(\mathrm{OX})$ and dithionite (DI).

spectroscopy. The solids were dialyzed with double distilled water. Then specific surface area and cation exchange capacity were determined by the BET method with $\mathrm{N}_{2}$ and $1 M \mathrm{MnCl}_{2}$ solution, respectively.

To study the ion exchange behaviour of the clay minerals after each extraction step, the minerals were shaken $12 \mathrm{~h}$ with $1 \mathrm{M}$ ammonium acetate at $\mathrm{pH} 7$ and a solid/solution ratio of 1:50. After centrifugation the concentrations of the extractable cations in solution such as $\mathrm{Ca}, \mathrm{Mg}$, and $\mathrm{K}$ were determined by atomic absorption spectroscopy.

\section{RESULTS}

Figs. 2a, 3a and 4a show the changes in the specific surface area and cation exchange capacity after each extraction step. The value of the untreated sample is 100 .

For all clay minerals the specific surface area shows a small increase after treatment with hydroxylamine and oxalate. After dithionite treatment a de- 
crease in specific surface area is observed, especially for smectite/illite where the value decreases by more than $70 \%$.

In the case of smectite/illite the cation exchange capacity shows no significant change after treatment with all three extractants; for illite a small decrease is observed. Only for kaolinite a continuous increase $(10-15 \%)$ of cation exchange capacity is observed.

Figs. $2 \mathrm{~b}, 3 \mathrm{~b}$ and $4 \mathrm{~b}$ show the element portions of $\mathrm{Si}, \mathrm{Al}, \mathrm{Fe}, \mathrm{K}, \mathrm{Ca}$ and $\mathrm{Mg}$ which are extracted in the single steps. It is obvious that the amounts of extracted $\mathrm{Fe}$ and $\mathrm{Si}$ from kaolinite and smectite/illite increase in a similar way after each treatment step. Also illite shows a continuous increase of these elements but the extracted $\mathrm{Si}$ portions are much higher than those of $\mathrm{Fe} . \mathrm{Al}$ is dissolved only by hydroxylamine and oxalate. For all studied clay minerals $\mathrm{Mg}$ and $\mathrm{K}$ are extracted only with hydroxylamine with the exception of $\mathrm{K}$ in the case of smectite/illite (see Fig. 4b). Ca is most affected in the first extraction step ( HY) and to a smaller extent by dithionite treatment. In the case of kaolinite only traces of Ca were extractable.

Ammonium acetate exchangeable cations were determined for untreated clay minerals and for the minerals after each extraction step. The results for the most important cations are given in Fig. 5. High exchangeable portions for $\mathrm{Ca}$, $\mathrm{Mg}$ and $\mathrm{K}$ after the hydroxylamine and oxalate extraction steps are seen in the smectite/illite and illite examples. In particular the exchangeable $\mathrm{K}$ amounts are of the same order of magnitude after each extraction step as for the untreated samples. This is also true for kaolinite while $\mathrm{Ca}$ and $\mathrm{Mg}$ are equally immobile.

\section{DISCUSSION}

The extractants used in this study turn out the following reduction processes with iron oxide:

I. $2 \mathrm{NH}_{2} \mathrm{OH}+2 \mathrm{Fe}_{2} \mathrm{O}_{3}+8 \mathrm{H}^{+} \longrightarrow 4 \mathrm{Fe}^{2+}+\mathrm{N}_{2} \mathrm{O}+7 \mathrm{H}_{2} \mathrm{O}$

II. $\mathrm{C}_{2} \mathrm{O}_{4}{ }^{2-}+\mathrm{Fe}_{2} \mathrm{O}_{3}+6 \mathrm{H}^{+} \longrightarrow 2 \mathrm{CO}_{2}+2 \mathrm{Fe}^{2+}+3 \mathrm{H}_{2} \mathrm{O}$

III. $\mathrm{S}_{2} \mathrm{O}_{4}{ }^{2-}+\mathrm{Fe}_{2} \mathrm{O}_{3}+6 \mathrm{H}^{+} \longleftrightarrow 2 \mathrm{SO}_{2}+2 \mathrm{Fe}^{2+}+3 \mathrm{H}_{2} \mathrm{O}$

During treatment with the extraction solutions the clay minerals change surface and ion exchange properties. The clay minerals also change their sorptive ability, particularly with respect to some heavy metals $(\mathrm{Cd}, \mathrm{Zn}, \mathrm{Ni})$ after removal of $\mathrm{Fe}$-oxide coatings with reducing extraction reagents (Helios-Rybicka, 1985). The clay minerals may be activated because cation exchange capacity increases for kaolinite, and the specific surface area increases for all minerals after extraction with hydroxylamine and oxalate solutions.

The decrease in the specific surface area after treatment with dithionite, 
significantly high for mixed-layer mineral smectite/illite suggests that the active sorption centers on surface and interlayer positions can be blocked by the complexing activity of the $\mathrm{S}_{2} \mathrm{O}_{4}{ }^{2-}$ ions or the cementing action of colloidal sulfur formed during treatment with dithionite solution by the reaction:

$$
2 \mathrm{~S}_{2} \mathrm{O}_{4}{ }^{2-}+4 \mathrm{H}^{+} \longrightarrow 3 \mathrm{SO}_{2}+\mathrm{S}+2 \mathrm{H}_{2} \mathrm{O}
$$

With no reagent iron is extracted completely. The largest amount is found for kaolinite and smectite/illite after dithionite treatment, for illite after the oxalate step. If clay minerals are not extracted sequentially but in singular steps the same course can be observed. Especially after dithionite treatment, however, only $50 \%$ of $\mathrm{Fe}$ is soluble compared to the sequential procedure.

Hence it follows that clay minerals are attacked by the reducing reagents. This can also be seen in the fact that after each extraction step a further exchange of cations with ammonium acetate is possible which could not be attained in the untreated samples of clay minerals. Particularly evident examples are $\mathrm{K}$ and $\mathrm{Mg}$ ( see Fig. 5).

$\mathrm{Al}$ and $\mathrm{Si}$ are found in the hydroxylamine and oxalate solutions, mainly in the case of illite followed by smectite/illite and kaolinite. The question whether it is amorphous $\mathrm{Al}$ and $\mathrm{Si}$, which is associated with iron oxide coatings or if it also originates from the clay mineral structure cannot be answered exactly. Xray and SEM studies did not give clear indications.

Considering the three extraction methods the oxalate/oxalic acid reaction seems to be the best method to dissolve the reducible iron compounds which may exist as discrete phases and coatings on clay minerals. In this step the smallest changes in surface properties, i.e. cation exchange capacity and specific surface area of kaolinite, illite and mixed layer smectite/illite, have been observed. On the other side the amount of dissolved iron is relatively high.

\section{REFERENCES}

Calmano, W. and Förstner, U., 1983. Chemical extraction of heavy metals in polluted river sediments in Central Europe. Sci. Total Environ., 28: 77-90.

Chao, L.L., 1972. Selective dissolution of manganese oxides from soils and sediments with acidified hydroxylamine hydrochloride. Soil Sci. Soc. Am. Proc., 36: 764-768.

Förstner, U. and Calmano, W., 1982. Bindungsformen von Schwermetallen in Baggerschlämmen. Vom Wasser, 59: 83-92.

Gibbs, R.J., 1977. Transport phases of transition elements in the Amazon and Yukon Rivers. Geol. Soc. Am. Bull., 88: 829-843.

Gupta, S.K. and Chen, K.Y., 1975. Partitioning of trace metals in selective chemical fractions of nearshore sediments. Environ. Lett., 10: 129-158.

Helios Rybicka, E., 1985. Role of clay-metal complexes in pollution mechanism. Conf. Ruolo dei Minerali Argillosi nelle Problematiche Ambientali. ENEA S. Teresa, 22.-23.5.

Holmgren, G.S., 1967. A rapid citrate-dithionite extractable iron procedure. Soil Sci. Soc. Am. Proc., 31: 210-211. 
Pfeiffer, G., Förstner, U. and Stoffers, P., 1982. Speciation of reducible metal compounds in pelagic sediments by chemical extraction. Senckenbergiana Marit., 14: 23-38.

Schwertmann, U., 1964. Differenzierung der Eisenoxide des Bodens durch photochemische Extraktion mit saurer Ammoniumoxalat-Lösung. Z. Pflanzenernähr. Düng. Bodenkd., 105: $194-202$. 